\title{
Focus Group and Delphi Process: Stroke and Potential Drug-Drug Interactions (pDDI) in The Neurological Intensive Care Unit (NICU)
}

\author{
Dejan Z. Aleksić1 , Pavle Z. Petković2, Miloš N. Milosavljević3 \\ Srđan M. Stefanovic ${ }^{4}$, Slobodan M. Janković ${ }^{3}$
}

\footnotetext{
${ }^{1}$ Department of Neurology, Faculty of Medical Sciences, University of Kragujevac, Serbia

2 Department of Radiology, Faculty of Medical Sciences, University of Kragujevac, Serbia

${ }^{3}$ Department of Pharmacology and toxicology, Faculty of Medical Sciences, University of Kragujevac, Serbia

${ }^{4}$ Department of Pharmacy, Faculty of Medical Sciences, University of Kragujevac, Serbia
}

\section{SUMMARY}

Introduction: The clinical significance of potential drug-drug interactions (pDDIs), especially in the intensive care unit (ICU) manifested mostly as adverse drug reactions.

Aim: The goal of this research was to conduct a focus group, in which the participants were decision- makers in acute ischemic stroke patient treatment. Also, the aim was to reach a consensus, due to the Delphi process, between neurologists and clinical pharmacologists regarding this highly vulnerable group of patients.

Material and Methods: In this academic research, so-called applied focus group (the goal was to reach practical decisions) and clinical focus group (determining motives, predeterminations, bias, prejudice and analyzing the behavior leading to a certain outcome) was done.

Results: Continuing medical education of neurologists is needed regarding pDDIs and the use of an online pDDIs checker. Certain groups of patients with AIS are at particular risk of exposure to pDDIs. Certain drug groups are more likely to interact with other drugs.

Conclusions: Defining medical recommendations/guidelines on evidence base medicine about pDDIs in patients with AIS would significantly contribute to reducing their frequency in this vulnerable patient population.

Keywords: Focus, Delphi, Stroke, Drug-Drug Interactions, Intensive Care Unit 


\section{INTRODUCTION}

Acute ischemic stroke (AIS) is a focal brain dysfunction that occurs as a result of decreased blood circulation and insufficient levels of oxygen and glucose for the neurons metabolic needs [1]. The effects of potential drug-drug interactions (pDDIs) can manifest as an increase or decrease in efficiency or change in the safety profile of one/both $\operatorname{drug}(\mathrm{s})$. The clinical significance of pDDIs, especially in the intensive care unit (ICU) reflected mostly in their ability to manifest as adverse drug reactions (ADR) $[2,3]$.

A focus group is conducted in relation to the medical situations without scientific consensus, with the goal for the participants to create practical solutions[4]. Intensivists and pharmacists in ICU had shown a significant differences in opinions and knowledge about clinically relevant DDI. Due to this, it has been advised that databases were to be formed, containing information regarding evidence and significance of pDDIs [5]. The focus group with the aim to examine the process in which physicians decide which anticoagulant therapy (warfarin or direct oral anticoagulant drugs (DOAC) to prescribe, have shown that participants were unable to select one of them, despite the awareness of the significance of the warfarin's potential for DDIin decision-making [6].

The Delphi technique is an expert consensus method used in research aimed at finding solutions to existing problems, generating ideas, or prioritizing them [7].Of the 139 pDDIs analyzed in the ICU settings, the experts reached a consensus and identified 86 pDDIs relevant to this environment during the two-phase Delphi process [8]. Pharmacists performed a review of literature discussing DDI and extracted 56 significant DDI, which were then considered by intensivists and the most important 28 drug pairs were selected, which indicated a high degree of disagreement between the two groups of experts[9]. Pharmacists have indicated that "signal fatigue" that occurs due to frequent electronic system warnings about pDDIs should be reduced with improving software capabilities and annual analysis of alerts from pharmacists [10]. The DDI and contraindication (drug-disease interactions) were among the top 5 of 18 categories with 160 indicators of polypharmacy or inadequate prescribing [11].
AIM

The goal of this research was to conduct a focus group, in which the participants were decision-makers in AIS patient treatment. Also, the aim was to reach the consensus, due to the Delphi process, of a neurologist (AIS experts) and clinical pharmacologists (experts for $\mathrm{pD}$ DIs) regarding this highly vulnerable group of patients.

\section{MATERIAL AND METHODS}

In this academic non-commercial research, the so-called applied focus group (the goal was to reach practical decisions) and clinical focus group (determining motives, predeterminations, bias, prejudice, and analyzing the behavior leading to a certain clinical outcome) was done. All seven invited participants were present at the meeting. Among the members of the focus group two were clinical pharmacologists $(\mathrm{CP})$, three members were neurologists $(\mathrm{N})$, one member was a clinical pharmacist $(\mathrm{P})$ and one was a nurse. A focus group members meeting was conducted on 10.4.2018, in the Clinical pharmacology Service at 1 p.m., and the topic being ,The pDDIs in AIS patients in a neurological intensive care unit (NICU)". The meeting lasted 29 minutes. The focus group meeting was led by an experienced moderator, CP, full-professor, in cooperation with a medical doctor, Ph.D. candidate in the field of neurosciences, and a neurology resident. After the data was collected in the form of audio recording, the transcription of the interview was performed. The text was analyzed following that. During the careful analysis, it has been concluded that the answers to the questions previously determined were obtained.

In the first round of the Delphi process, questions were emailed to neurologists specializing in the treatment of AIS $(n=19)$, from four Clinical Centers of Serbia and Republika Srpska. In addition, questions were also sent to two CP from the Clinical Pharmacology Service of the Clinical Center Kraguje$\operatorname{vac}(\mathrm{CCK})$.

The questions sent to experts in the first round of the Delphi method were presented in table 1.

The six neurologists and one clinical pharmacologist $(n=7)$ wrote their answers. A detailed analysis of all responses was performed. The summation of the answers rep- 
Do you consider potential drug-drug interactions (pDDIs) to be significant in patients with acute ischemic stroke (AIS)? Why?

What measures do you think should be taken to raise the level of knowledge and awareness among neurologists of the existence of pDDIs in patients with AIS?

3 Did you hear/use or are you unaware of the existence of

4 Have you had any experience with DDI in neurological intensive care unit (NICU)?

5 What is your opinion on factors that may be important for exposure of patients with AIS to pDDIs?

5 List as many relevant factors as you can and explain their impact on this topic.

6 Are the some subgroups of patients with AIS at higher risk of being exposed to pDDIs?

7 Are patients with certain comorbidities at greater risk of exposure to pDDIs and why?

8 Do you find that particular drug groups have a particularly high frequency in pDDIs?

9 What measures can be taken at the individual and each NICU level in daily practice to reduce exposure to pDDIs of patients with AIS?

10 What measures can be taken at the national level to reduce the exposure to pDDIs?
Table 1. The questions sent to experts in the first round of the Delphi method resented all the answers offered by the participants for each individual question. The conclusion summation was emailed to the respondents from the first round. Respondents were advised to critically approach the summary conclusions and to state whether they agreed with it. All respondents who answered in the first round of the survey answered in the second round. After receiving the reply from the second round of correspondence, a summary of all the conclusions, which all participants agreed on was reached, and topics on which there was no consensus.

\section{RESULTS}

\section{Understanding the significance of the pDDIs in NICU patients}

All focus group members declared that pDDIs were serious problems, and the neurologists considered that more attention has been paid to this problem now than in the years before.

\section{Analysis of the insufficient knowledge about pDDIs in patients in NICU}

The neurologists' attitude was that the pDDI problem is not underestimated and that the opinion that pDDI was insignificant was nonexistent among neurologists. N1 „I think that everyone understands that DDI is important". The neurologists also mentioned the difficult process of confirming DDI occurring in a clinical setting as one of the reasons for the insufficient awareness and knowledge about pDDI. The interaction between warfarin and amiodarone was cited as an example, which can mani- fest by an increase in INR, but the increase in INR was insufficient evidence that DDI actually happened. The CP1 stated that, for a complex patient, examining the possibility of DDI could take at least 20 to 30 minutes, while the $P$ gave his view of the problem as $\mathbf{P}$ „In my opinion, DDI is one aspect of the pharmaceutical practice that has potential, that isn't practiced by us because of known reasons - insufficient staff". The reasons for the unawareness of the existence of online checker for pDDI were highlighted by neurologists. During their residency program, as in their everyday physician work, the neurologists haven't encountered pDDI checkers, and routine pDDI checks for patients in NICU using online checkers were not performed.

\section{Determining the degree of knowledge and awareness regarding online pDDIs checkers}

There was a difference in knowledge and awareness regarding online pDDIs checkers. The CP considered that checking for the pDDI and making a decision after determining the existence of the pDDIs as an additional service, especially regarding critical patients. CP1: "I think that it is a complicated service, very sophisticated, that is, considering all the facts, hardly feasible, judging from the aspect of an intensive care unit physician and having the complexity of the matter in mind". On the other side, the neurologists and the nurse have shown unawareness of that aspect of the pDDI problem. They all agreed that one of the disadvantages is the lack of online checkers in the Serbian language, which prevents their wider use. 
Analyzing the experience regarding DDI in AIS patients in NICU

The neurologists have highlighted groups of drugs that are more likely to interact with other drugs. N1 "I for the matter of fact know that we paid attention to antiepileptic drugs, because one of them can influence the other one because different drugs can affect antiepileptic drugs, where even a small change in drug concentration can lead to seizure, so we paid attention to that". The example of the interaction between lamotrigine and valproic acid was highlighted. In the patient in question, Steven-Johnson syndrome occurred. The neurologists have also shown knowledge of the anticoagulant DDI, which was significantly often prescribed for patients with AIS in NICU. N2 "Nowadays, as before, we pay attention to warfarin/amiodarone and dabigatran/verapamil".

\section{Possibilities of improvement in the area of pDDI in NICU patients}

The first proposition is additional education of all neurologists and nurses with a goal to encompass familiarization with DDI checkers available online. The second phase would be the phase of routine use of online pDDIs checkers. The third phase would be analysis of discovered pDDI, in order to evaluate the current situation. After a period (several months) of routine use of pDDI checkers, the pDDI presence would be analyzed once again. That way, evaluation of conducted measures could be performed and eventual pDDI frequency reduction in NICU patients could be observed. THE next measure would be to post tables with the most common pDDI in NICU, serving as a reminder. Having clinical pharmacologists create a mini-guide or a brochure regarding the most common pDDIs would also be one of the ways to raise the awareness of pDDI. The neurologists considered time to be the main problem regarding the proposition of online DDI checkers in the NICU. The complexity of the whole pDDIs problem, decision making when they receive pDDI information, and the fact that it exceeds their education level were in the second place. On the other hand, having clinical pharmacists perform this would be hardly achievable, due to the insufficient staff numbers. All neurologists agreed that using online pDDI checkers, analyzing the patient with all comorbidities and making a clinical decision, is a complex additional service that would require clinical pharmacologist/pharmacists to be included. The clinical pharmacologists agreed that a routine checking of the most common $\mathrm{pD}$ DIs, regarding anticoagulant and antiepileptic drugs, could be performed by a neurologist, however, it is necessary to consult a clinical pharmacologist for a pDDI analysis in case of every clinically unstable patient. The clinical pharmacist considered that introducing a program of electronic drug prescription might be a good practice. Clinical pharmacologists considered artificial intelligence to be the ultimate solution to the problem of pDDI. CP1: „But I think its future, generally speaking, it's far away, it's not now, but artificial intelligence is going to be the future, it could oversee the amount the information existing there, which cannot be monitored by a human now".

The results from Delphi process showed that pDDIs in patients with AIS treated in NICU were very important because these patients were a "vulnerable population" suffering from a "serious, life-threatening disease" in which pDDIs can lead to "clinical/neurological decompensation” and thus affect the „outcome of hospitalization". A basic measure of raising the level of knowledge proposed among neurologists about the pDDIs was education. Several levels have been suggested, ranging from the "mandatory knowledge of pDDIs defined in the Integrated academic studies for a Doctor of Medicine and Master of Pharmacy and neurology residency program", through the "insistence of the NICU experts to think about the pDDIs before the introduction of new drug with a special reminder for young physician", "introducing a clinical pharmacologist into the everyday NICU functioning that will take care of pDDIs", as well as "rationalizing prescribing, the correction of the dose of drugs which interact with other drugs...". Familiarity with online checkers for pDDIs is partial and insufficient in neurologists, while clinical pharmacologists use checkers in their everyday work and know many types of these (Medscape, Micromedex,...) as well as other sources of information about pDDIs, such as printed literature. Half of the respondents could not recall any DDI in the NICU (,no immediate personal experience"). The others cited the following examples: warfarin and barbiturates, serotonin reuptake inhibitors (SSRIs) and non-steroid anti-inflammatory drugs (NSAIDs). The clini- 
cal pharmacologists made advice that pDDIs online checkers data were not always and completely reliable and that it should be checked from other sources of pDDIs literature. Important factors for exposure to pDDIs were older age, impaired adaptive compensatory mechanisms, possible decreased hepatobiliary system and kidney function, numerous comorbidities, polypharmacy, certain groups of drugs such as anticoagulant therapy, antibiotics, and numerous complications during treatment in this group of patients. Additionally, several subgroups of patients are at particular risk of pDDIs: patients with compromised cardiovascular function, metabolic distress syndrome, atrial fibrillation, septic patients, and autoimmune diseases. Groups of drugs and some drugs that have a particularly high incidence in pDDIs are liver enzyme inducers, hemostatic agents, neuroleptics, antiepileptic, antibiotics, antiplatelet, antifungals, NSAIDs, digoxin, amiodarone, aminophylline. Measures that could be taken in daily practice to reduce exposure to pDDIs were education at all levels of schooling, and then through defining recommendations/guidelines „evidencebased" medicine or expert consensus on the most common pDDIs. The assistance of clinical pharmacologists has also been suggested, for daily monitoring of patients and rationalization of medication prescribing. Measures that could be taken at the national level were introducing pDDIs online checkers into everyday clinical practice at NICU, forming a team of experts who, through various training methods (e.g. printed material) presented the clinically significant pDDIs and continuing medical education of physicians.

\section{DISCUSSION}

The focus group showed that addressing the poor knowledge of neurologists about pDDIs and the utility of pDDIs software required the implementation of continuing medical education programs with the involvement of all healthcare professionals involved in prescribing therapy, as well as the routine use of online available tools for checking pDDIs in clinical practice. The experts in the Delphi process agreed that it is necessary to define recommendations in the form of a evidence-based medicine guideline on PDDI in patients with AIS.

Physicians' knowledge about DDI was generally poor [12], and specialists were less likely to correctly identify DDI compared with generalists [13]. Also, knowledge of neurologists about the interactions of antiepileptic drugs and hormonal contraceptives was insufficient [14]. The difference between the intensivists and pharmacists in the perception of warnings issued by an electronic pDDI program in the ICU and different knowledge regarding pDDIs has been shown [5]. We presented similar disagreements between the neurologist and the clinical pharmacologists/ pharmacist. However, a consensus regarding the importance of pDDIs and steps required to reduce pDDI in NICU was achieved. Health information system (HIS), currently in use in the CCK, does not provide pDDI warnings, however, it is one of the measures which could improve the situation in the area of pDDI [15]. The lack of time and staff in everyday neurological practice was highlighted multiple times by the focus group participants as an important factor negatively affecting the neurologists' motivation to deal with pDDIs in a more detailed manner. For this reason, it is very important for all physicians to become familiar with the most important aspects of DDI, some of them life-threatening [16]. The importance of experience with a particular DDI on its future recognition in everyday practice has been demonstrated before [13] and oral anticoagulants pDDI were emphasized as an example in our focus group. Similar to our focus group, in another study, due to the numerous warfarin interactions with drugs, food and comorbidities and frequent and regular INR monitoring, on the other hand, due to the rare pDDIs and simpler dosage of DOAC, the DOAC was favored [6]. Experts' consensus has also shown that pDDIs should always be taken into account when prescribing DAOCs and that this group of drugs should be considered the first choice in patients at high risk for intracranial hemorrhage [17]. However, current guidelines do not offer recommendations how to avoid the pDDI of this group of drugs in elderly patients with numerous comorbidities and polypharmacy[18]. But, considering that neurology is an area of medicine in which new drugs are developing very quickly, the knowledge of neurologists about all aspects of drugs, including DDI, is very significant [19].

"A boy crying wolf and nobody paying any attention to him" was one of the quotes from the participants who agreed that it is nec- 
essary to change the specificity of the online pDDIs checkers' warnings, thus reducing the number of warnings, while increasing their significance, i.e. working to increase the pDDI checkers' specificity [20]. Important elements that the pDDIs warning of electronic systems should include were the names of interacting drugs, the seriousness of pDDI, clearly describing the potential clinical consequences, the mechanism of the pDDI, predisposing factors (co-morbidity or lab values), recommended actions and evidence [21]. All these tips should be kept in mind while using the pDDI checkers in NICU patients, therefore, the alert that would warn of pDDIs should provide more information regarding the clinical significance of detected pDDIs. During the Delphi process our experts agreed that online pDDIs checkers were very important, although clinical pharmacologists have stated that $\mathrm{pD}$ DIs data were not completely reliable and advised that they should be checked from other literature about pDDIs. Comparisons of three different online pDDIs and FDA-approved labels have shown a significant difference in the type and frequency of antiepileptic drugs $\mathrm{pD}$ DIs [22]. The disadvantages of computer programs for pDDIs, which have also been cited in the literature, were a large number of falsepositive alerts, the absence of history interaction management, the lack of timely updates to the database, and the absence of clear guidelines for managing interactions. The most important tips that come from the literature for improving pDDIs programs were to configure software that will provide better information about the options available and in which basic databases will be updated more quickly [10]. The experts for DDI stated used different data about DDI information: PubMed, Google Scholar, Google Web Search, EMBASE, Lexicomp, Micromedex, DrugsFDA, DailyMed and Facts and Comparisons [23].

Nonetheless, the advantages of working in NICU, regarding the insight into pDDIs, were the ability to access all data about the patients' diagnoses, prescribed therapy, timing and way of administration, drug doses, and having the possibility to monitor the pDDIs effect on clinical presentation and comorbidities, as well as the manifestation of therapyrelated ADR. The absence of these advantages represents a great problem for the physicians working in the emergency department (ED). Physicians in the ED usually don't have suffi- cient clinically significant patient data, especially regarding the patient's therapy, which they could base their decision on, which is prominent in case of multiple physicians deciding on the therapy course and having no final report on the patient's condition on release from the ED [15]. Among the neurologists in the focus group participants, the most wellknown were the interactions of antiepileptic drugs. Although epilepsy is the most common chronic neurological disease requiring regular pharmacotherapy, the frequency of pDDIs in these patients was not high, but antiepileptic drugs have a high potential to interact with other drugs [24]. While the experts reached a consensus on the interactions between NSAIDs and SSRIs, whose concomitant administration may increase the risk of gastrointestinal bleeding [25], attention was drawn to the importance of anticoagulant therapy pDDIs by all participants in the study. Almost daily new information about interactions of anticoagulant drugs requires regular updating knowledge in order to treat patients with this group of drugs properly [26].

Experts from the Delphi process highlight the risk factors for pDDIs that have been shown in previous studies. Due to the great importance of the hepatobiliary system in drug metabolism, impaired function of this system may be a significant risk factor for $\mathrm{pD}$ DIs [27]. Because many drugs were used for metabolic syndrome, it could indirectly increase the likelihood of exposure of these patients to pDDIs [28]. A change in pharmacokinetics and pharmacodynamics occurs during sepsis [29] and studies have shown a relatively high frequency of pDDIs in patients with sepsis treated in ICU [30]. Also, the patients with autoimmune disease were significantly exposed to pDDIs [31].

The importance of particular groups of drugs and individual drugs in pDDIs has already been noted earlier, and our members of the Delphi process have also reached a consensus for antimicrobials [32], antifungals [33], NSAIDs [34], digoxin [35], aminophylline [36], amiodarone [37]. A systematic review on potentially inappropriate medication in the elderly analyzed 36 studies, 32 of which were conducted by the Delphi technique. The authors showed that benzodiazepines and NSAIDs were the most commonly inappropriate drug groups and diazepam, chlordiazepoxide, indomethacin, and amitriptyline were po- 
tentially inappropriate drugs. They identified 159 pDDIs with the most prevalent following drug groups: NSAIDs, tricyclic antidepressants, angiotensin-converting-enzyme-inhibitors and SSRIs. The most common pDDIs were warfarin and NSAIDs, while warfarin was the most common drug in pDDIs [38], which was a significant topic among our focus group members.

The conclusions of our experts about improving knowledge of neurologists about pDDIs included education about pDDIs, the assistance of clinical pharmacologists/pharmacists, introducing a pDDIs online checkers into everyday clinical practice, define the recommendations/guides of „evidence-based” medicine on pDDIs in patients with AIS and the ultimate solution in the pDDI field will be artificial intelligence. Literature confirmed that educational pharmacotherapy programs for cardiologists reduced the indicators of the clinically significant DDI by $18 \%$ [39]. The DDI was among the three most common drug-related problems (DRP) among neurological patients detected by clinical pharmacists [40] and the role of critical care pharmacists in reducing the risk of patient exposure to clinically important DDI in the ICU was significant [41]. From $83 \%$ to $90 \%$ of clinical pharmacists' advices about DRP in the neurological settings were accepted $[40,42,43]$. The factor that increased the likelihood of more than three times that advice from clinical pharmacologists being accepted from neurologist was high-risk DDI[44]. And in the stroke unit, in particular, about $10 \%$ of DRP identified by clinical pharmacists were due to DDI [43]. Experts conclude that it is urgent to develop meaningful DDI databases for physicians and pharmacists and improve their education [45], and also other experts made the following recommendations: the quality and level of evidence for the harmfulness of DDI, the pharmacological basis for pDDIs, the severity and incidence of ADR associated with pDDIs, the clinical significance of pDDIs at the patient and population levels, patient risk factors for pDDIs and the quality of evidence for those risks, what measures to take for $\mathrm{pD}$ DIs and the strength of this recommendations, when to start them and when to stop taking measures, how to monitor, provide a set of symbols, letters for successful communication and provide clarification of the same [10]. The existence of a unified national ADR spontane- ous reporting system and using certain statistical methods could provide retrospective detection of signals of certain drug pairs (DDIs) manifesting as ADR [46]. Authors applied a machine learning (ML) based method that could be used as a tool to help researchers to identify potential DDIs [47], so we can say that artificial intelligence in drug treatment has become the present [48].

\section{CONCLUSION}

Continuing medical education of neurologists is needed regarding pDDIs and the use of an online pDDIs checker. Certain groups of patients with AIS are at particular risk of exposure to pDDIs. Certain drug groups are more likely to interact with other drugs. Defining medical recommendations/guides on evidence base medicine about pDDIs in patients with AIS would significantly contribute to reducing their frequency in this vulnerable patient population.

\section{ACKNOWLEDGMENTS}

This study was partially financed by grant No 175007, given by Serbian Ministry of Education, Science and Technical Development.

\section{CONFLICT OF INTEREST}

All authors declare no conflict of interest.

\section{REFERENCES}

1. Hankey GJ. Stroke. Lancet. 2017; 389(10069):641-54.

2. Fitzmaurice MG, Wong A, Akerberg H, Avramovska S, Smithburger P, Buckley MS, Kane-Gill SL. Evaluation of Potential Drug-Drug Interactions in Adults in the Intensive Care Unit: A Systematic Review and Meta-Analysis. Drug Saf. 2019; 42(9):1035-44.

3. Zheng WY, Richardson LC, Li L, Day RO, Westbrook JI, Baysari MT. Drug-drug interactions and their harmful effects in hospitalised patients: a systematic review and meta-analysis. Eur J Clin Pharmacol. 2018; 74(1):15-27.

4. Wong LP. Focus group discussion: a tool for health and medical research.Singapore Med J. 2008;49(3):256-60.

5. Askari M, Eslami S, Louws $M$, Dongelmans $D$, Wierenga $P$, Kuiper R, Abu-Hanna A. Relevance of drug-drug interaction in the ICU - perceptions of intensivists and pharmacists. Stud Health Technol Inform. 2012; 180:716-20. 
6. Eek AK, Øie E, Granas AG. Prescribing of NOACs has outnumbered warfarin: exploring how physicians choose anticoagulant treatments. Eur J Clin Pharmacol. 2018; 74(3):323-30.

7. McMillan SS, King M, Tully MP. How to use the nominal group and Delphi techniques.Int $\mathrm{J}$ Clin Pharm. 2016; 38(3):655-62.

8. Bakker T, Klopotowska JE, de Keizer NF, van Marum R, van der Sijs $\mathrm{H}$, de Lange DW, Abu-Hanna A, Dongelmans DA, SIMPLIFY Study Group. Improving medication safety in the Intensive Care by identifying relevant drug-drug interactions - Results of a multicenter Delphi study [published online ahead of print, 2020 Feb 21]. J Crit Care. 2020; 57:134-40.

9. Malone DC, Abarca J, Hansten PD, Grizzle AJ, Armstrong EP, Van Bergen RC, Duncan-Edgar BS, Solomon SL, Lipton RB. Identification of serious drug-drug interactions: results of the partnership to prevent drug-drug interactions. J Am PharmAssoc (2003). 2004; 44(2):142-51.

10. Bagri H, Dahri K, Legal M. Hospital Pharmacists' Perceptions and Decision-Making Related to Drug-Drug Interactions. Can J Hosp Pharm. 2019; 72(4):288-94.

11. Floor-Schreudering A, Geerts AF, Aronson JK, Bouvy ML, Ferner RE, De Smet PA. Checklist for standardized reporting of drug-drug interaction management guidelines.Eur J Clin Pharmacol. 2014; 70(3):313-8.

12. Ko Y, Malone DC, Skrepnek GH, Armstrong EP, Murphy JE, Abarca J, Rehfeld RA, Reel SJ, Woosley RL. Prescribers' knowledge of and sources of information for potential drug-drug interactions: a postal survey of US prescribers. Drug Saf. 2008; $31(6): 525-36$.

13. Ko Y, Malone DC, D'Agostino JV, Skrepnek GH, Armstrong EP, Brown M, Woosley RL. Potential determinants of prescribers' drug-drug interaction knowledge. Res Social Adm Pharm. 2008; $4(4): 355-66$.

14. Suto HS, Braga GC, Scarpellini GR, Takeuchi LI, Martins AP, Leite J, Vieira CS. Neurologist knowledge about interactions between antiepileptic drugs and contraceptive methods. Int J Gynaecol Obstet. 2016; 134(3):264-7.

15. Rahmner PB, Eiermann B, Korkmaz S, Gustafsson LL, Gruvén M, Maxwell S,Eichle HG, Veg A. Physicians' reported needs of drug information at point of care in Sweden. Br J Clin Pharmacol. 2012; 73(1):115-25.

16. Day RO, Snowden L, McLachlan AJ. Life-threatening drug interactions: what the physician needs to know. Intern Med J. 2017; 47(5):501-12.

17. Rossini R, Quadri G, Rognoni A, Nardi F, Varbella $F$, Musumeci G. Use of DOACs in real-world challenging settings: a Delphi Consensus from Italian cardiologists. Minerva Cardioangiol. 2019; 67(5):361-73.
18. Foerster KI, Hermann S, Mikus G, Haefeli WE. Drug-Drug Interactions with Direct Oral Anticoagulants [published online ahead of print, $2020 \mathrm{Mar}$ 11]. ClinPharmacokinet. 2020;10.1007/s40262-02000879-x. doi:10.1007/s40262-020-00879-x.

19. Nomoto M, Nagai M, Nishikawa N, Tsujii T, Iwaki $\mathrm{H}$. Essential Knowledge of Drugs for Neurologists on Pharmacokinetics and Drug Development in Global Aspects to the World. Rinsho Shinkeigaku. 2013; 53(11):907-10.

20. Lapane KL, Waring ME, Schneider KL, Dubé C, Quilliam BJ. A mixed method study of the merits of e-prescribing drug alerts in primary care. J Gen Intern Med. 2008; 23(4):442-6.

21. Payne TH, Hines LE, Chan RC, Hartman S, Kapusnik-Uner J, Russ AL, Chaffee BW,

Hartman C, Tamis V, Galbreth B, Glassman PA, Phansalkar S, van der Sijs H, Gephart SM, Mann G, Strasberg HR, Grizzle AJ, Brown M, Kuperman GJ, Steiner C, Sullins A, Ryan H, Wittie MA, Malone DC. Recommendations to improve the usability of drugdrug interaction clinical decision support alerts. J Am Med Inform Assoc. 2015; 22(6):1243-50.

22. Ekstein D, Tirosh M, Eyal Y, Eyal S. Drug interactions involving antiepileptic drugs: assessment of the consistency among three drug compendia and FDA-approved labels. Epilepsy Behav.2015; 44:21824.

23. Grizzle AJ, Horn J, Collins C, Schneider J, Malone DC, Stottlemyer B, Boyce RD. Identifying Common Methods Used by Drug Interaction Experts for Finding Evidence About Potential Drug-Drug Interactions: Web-Based Survey. J Med Internet Res. 2019;21(1):e11182. Published 2019 Jan 4. doi:10.2196/11182

24. Bosak M, Stowik A, Iwańska A, Lipińska M, Turaj W. Co-medication and potential drug interactions among patients with epilepsy. Seizure. 2019; 66:47-52.

25. Mort JR, Aparasu RR, Baer RK. Interaction between selective serotonin reuptake inhibitors and nonsteroidal antiinflammatory drugs: review of the literature. Pharmacotherapy. 2006; 26(9):1307-13.

26. Vazquez SR. Drug-drug interactions in an era of multiple anticoagulants: a focus on clinically relevant drug interactions. Blood. 2018; 132(21):2230-39.

27. Swift B, Pfeifer ND, Brouwer KL. Sandwichcultured hepatocytes: an in vitro model to evaluate hepatobiliary transporter-based drug interactions and hepatotoxicity. Drug Metab Rev. 2010; 42(3):446-71.

28. Mendrick DL, Diehl AM, Topor LS, Dietert RR, Will Y, La Merrill MA, Bouret S, Varma V, Hastings KL, Schug TT, Emeigh Hart SG, Burleson FG. Metabolic Syndrome and Associated Diseases: From the Bench to the Clinic. Toxicol Sci. 2018; 162(1):36-42.

29. De Paepe P, Belpaire FM, Buylaert WA. Phar- 
macokinetic and pharmacodynamic considerations when treating patients with sepsis and septic shock. ClinPharmacokinet. 2002; 41(14):1135-51.

30. Caribé RA, Chaves GR, Pocognoni JD, Souza IA. Potenciales interacciones medicamentosa sen pacientes con sepsis internadosen la unidad de terapija intensiva [Potential drug interactions in patients with sepsis admitted to the intensive care unit]. Farm Hosp. 2013; 37(5):383-7.

31. Pflugbeil S, Böckl K, Pongratz R, Leitner $M$, Graninger W, Ortner A. Drug interactions in the treatment of rheumatoid arthritis and psoriatic arthritis. Rheumatol Int. 2020; 40(4):511-21.

32. Kuscu F, Ulu A, Inal AS, Suntur BM, Aydemir H, Gul S, Ecemis K, Komur S, KurtaranB,OzkanKuscu $0, \&$ Tasova Y. Potential Drug-Drug Interactions with Antimicrobials in Hospitalized Patients: A Multicenter Point-Prevalence Study. Medical science monitor: international medical journal of experimental and clinical research. 2018;24:4240-47.

33. Lempers VJ, Brüggemann RJ. Antifungal therapy: drug-drug interactions at your fingertips. J AntimicrobChemother. 2016; 71(2):285-9.

34. Wongrakpanich S, Wongrakpanich A, Melhado K, Rangaswami J. A Comprehensive Review of NonSteroidal Anti-Inflammatory Drug Use in The Elderly. Aging Dis. 2018; 9(1):143-50.

35. Fenner KS, Troutman MD, Kempshall S, Cook JA, Ware JA, Smith DA, Lee CA. Drug-drug interactions mediated through P-glycoprotein: clinical relevance and in vitro-in vivo correlation using digoxin as a probe drug. Clin Pharmacol Ther. 2009; 85(2):73-181.

36. Ajimura CM, Jagan N, Morrow LE, Malesker MA. Drug Interactions With Oral Inhaled Medications. J Pharm Technol. 2018; 34(6):273-80.

37. Srinivasan $M$, Ahmad L, Bhindi R, Allahwala U. Amiodarone in the aged. Australian Prescriber. 2019; 42(5):158-62.

38. Motter FR, Fritzen JS, Hilmer SN, Paniz ÉV, Paniz VMV. Potentially inappropriate medication in the elderly: a systematic review of validated explicit criteria. Eur J Clin Pharmacol. 2018; 74(6):679-700.

39. Mussina AZ, Smagulova GA, Veklenko GV, Tleumagambetova BB, Seitmaganbetova NA, Zhaubatyrova AA, Zhamaliyeva LM. Effect of an educational intervention on the number potential drug-drug interactions. Saudi Pharm J. 2019; 27(5):717-23.

40. Ali MAS, Khedr EMH, Ahmed FAH, Mohamed NNE. Clinical pharmacist interventions in managing drug-related problems in hospitalized patients with neurological diseases. Int J Clin Pharm. 2018; 40(5):1257-64.

41. Rivkin $\mathrm{A}$, Yin $\mathrm{H}$. Evaluation of the role of the critical care pharmacist in identifying and avoiding or minimizing significant drug-drug interactions in medical intensive care patients. J Crit
Care. 2011;26(1):104.e1-104.e1046. doi:10.1016/j. jcrc.2010.04.014.

42. Rodrigues JPV, Marques FA, Gonçalves AMRF, et al. Analysis of clinical pharmacist interventions in the neurology unit of a Brazilian tertiary teaching hospital. PLoS One. 2019;14(1):e0210779. Published 2019 Jan 18. doi:10.1371/journal.pone.0210779.

43. Semcharoen K, Supornpun S, Nathisuwan S, Kongwatcharapong J. Characteristic of drug-related problems and pharmacists' interventions in a stroke unit in Thailand. Int J Clin Pharm. 2019; 41(4):880-7.

44. Taegtmeyer AB, Curkovic I, Corti N, Rosen C, Egbring M, Russmann S, Gantenbein AR, Weller M, Kulak-Ublick GA. Drug-related problems and factors influencing acceptance of clinical pharmacologists ` alerts in a large cohort of neurology inpatients. Swiss Med Wkly. 2012;142:w13615. Published 2012 Jul 9. doi:10.4414/smw.2012.13615

45. Levy RH, Ragueneau-Majlessi I. Past, Present, and Future of Drug-Drug Interactions. Clin Pharmacol Ther. 2019;105(6):1286-8.

46. Noguchi Y, Tachi T, Teramachi H. Review of Statistical Methodologies for Detecting Drug-Drug Interactions Using Spontaneous Reporting Systems. Front Pharmacol. 2019;10:1319.

47. Kastrin A, Ferk P, Leskošek B. Predicting potential drug-drug interactions on topological and semantic similarity features using statistical learning. PLoS One. 2018; 13(5):e0196865. doi: 10.1371/ journal.pone.0196865. PMID: 29738537; PMCID: PMC5940181.

48. Romm EL, Tsigelny IF. Artificial Intelligence in Drug Treatment. Annu Rev Pharmacol Toxicol. 2020; 60:353-69. 


\section{Fokus grupa i Delfi proces: moždani udar i potencijalne interakcije lekova (PIL) u neurološkoj jedinici intenzivne nege (NJIN)}

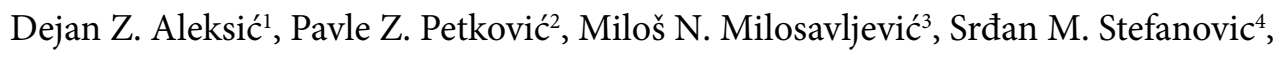
Slobodan M. Janković ${ }^{3}$

\footnotetext{
${ }^{1}$ Katedra neurologije, Fakultet medicinskih nauka, Univerzitet u Kragujevcu, Kragujevac, Srbija

${ }^{2}$ Katedra radiologije, Fakultet medicinskih nauka, Univerzitet u Kragujevcu, Kragujevac, Srbija

${ }^{3}$ Katedra farmakologije i toksikologije, Fakultet medicinskih nauka, Univerzitet u Kragujevcu, Kragujevac, Srbija

${ }^{4}$ Katedra farmacije, Fakultet medicinskih nauka, Univerzitet u Kragujevcu, Kragujevac, Srbija
}

\section{KRATAK SADRŽAJ}

Uvod: Klinički značaj potencijalnih interakcija lekova (PIL), posebno u jedinici intenzivne nege (JIN), ogleda se uglavnom u njihovoj sposobnosti da se manifestuju kao neželjene reakcije na lekove.

Cilj: Cilj ovog istraživanja bio je sprovesti fokus grupu u kojoj su učesnici bili donosioci odluka u lečenju pacijenata sa akutnim ishemijskim moždanim udarom (AIMU). Takođe, cilj je bio da se postigne konsenzus, tokom Delfi procesa, neurologa i kliničkih farmakologa u vezi sa ovom izuzetno ranjivom grupom pacijenata.

Metodologija: U ovom akademskom istraživanju urađena je takozvana primenjena fokus grupa (cilj je bio donošenje praktičnih odluka) i klinička fokus grupa (utvrđivanje motiva, predodređenja, pristrasnosti, predrasuda i analiza ponašanja koja vode do određenog ishoda).

Rezultati: Potrebna je kontinuirana medicinska edukacija neurologa u vezi sa PIL i upotrebom online alata za proveru PIL. Određene grupe pacijenata sa AIMU su u posebnom riziku od izloženosti PIL. Određene grupe lekova imaju veću verovatnoću interakcije sa drugim lekovima.

Zaključak: Definisanje medicinskih preporuka/vodiča na osnovu medicine zasnovane na dokazima o PIL kod pacijenata sa AIMU značajno bi doprinelo smanjenju njihove učestalosti u ovoj ugroženoj populaciji pacijenata.

Ključne reči: fokus, delfi, moždani udar, interakcije lekova, intenzivna nega 